\title{
DOI 10.26886/2414-634X.4(23)2018.1
}

UDC: $336.13: 336.64: 314.2$

STATE-PRIVATE PARTNERSHIP IN THE FIELD OF HEALTH

PROTECTION: FINANCIAL AND SOCIAL ASPECTS OF

MODERNISATION

\section{O. V. Petrushka, PhD in Economical Sciences}

Ternopil National Economic University, Ukraine, Ternopil

Basic properties of state-private partnership as alternatives of the budgetary financing of medical industry are reflected in the article, foreign experience of the general use of private investments and state financial resources is considered in the system of health protection. An author found out the basic terms of input of state-private partnership, the row of socioeconomic effects is certain for his participants during realization of general projects. In the process of research the methods of dialectical analysis and synthesis, comparison, logical generalization and formalization were used. Positive properties and potential risks of input of state-private partnership are certain in home practice. The offered measures are for stimulation of forms of co-operation of business and power with the aim of development of competition and upgrading and availability of medical services.

Key words: state-private partnership, health protection, private investor, modernisation of medical industry, development of national economy.

кандидат економічних наук, Петрушка О. В. Державно-приватне партнерство у сфрері охорони здоров'я: фрінансові та соціальні аспекти модернізації/ Тернопільський національний економічний університет, Україна, Тернопіль

У статті висвітлено основні властивості державно-приватного партнерства як альтернативи бюджетного фрінансування медичної галузі, розглянуто зарубіжний досвід спільного використання приватних інвестицій і державних фрінансових ресурсів у системі охорони здоров'я. 
Автором з'ясовано основні умови запровадження державно-приватного партнерства, визначено ряд соціально-економічних ефектів для його учасників в ході реалізації спільних проектів. У процесі дослідження були використані методи діалектичного аналізу та синтезу, порівняння, логічного узагальнення та формалізації. Визначено позитивні властивості та потенційні ризики запровадження державноприватного партнерства у вітчизняній практиці. Запропоновані заходи для стимулювання фрорм взаємодії бізнесу та влади з метою розвитку конкуренції і підвищення якості та доступності медичних послуе.

Ключові слова: державно-приватне партнерство, охорона здоров'я, приватний інвестор, модернізація медичної галузі, розвиток національної економіки.

Вступ. Вітчизняна система охорони здоров'я характеризується існуванням низки проблем і потребує пошуку інноваційних інструментів, методів та механізмів управління нею. Однак через обмеженість фрінансових ресурсів державного сектору економіки питання залучення приватних інвестицій у медичну галузь $є$ досить актуальним. Така взаємодія відносин дозволить об'єднати фрінансові і трудові ресурси держави та бізнесу, що сприятиме підвищенню ефективності їх використання та дозволить мінімізувати ризики.

Питання запровадження державно-приватного партнерства та особливостей його фрункціонування у системі охорони здоров'я висвітлюються у численних публікаціях зарубіжних та вітчизняних вчених: В. Варнавського [4], М. Добрусіної [6], Р. Жердєва [1], О. Мартякової [8], К. Павлюк [7], Т. Панової [3], Б. Шулюк [2] та ін. Проте, незважаючи на значну кількість наукових досліджень з окресленої проблематики, теоретичні та практичні аспекти партнерства влади та 
приватного сектору у медичній галузі потребують більш глибокого вивчення та дослідження.

Метою статті $€$ обґрунтування науково-теоретичних аспектів розвитку державно-приватного партнерства в системі охорони здоров'я та визначення ефрективності його запровадження в Україні.

Виклад основного матеріалу. Інститут партнерства державного та приватного секторів являє собою не тільки об'єднання фрінансових, економічних, інтелектуальних та трудових ресурсів, а й виступає інституційно-організаційним поєднанням переваг державної публічної влади і приватного підприємницького сектору 3 метою вирішення суспільно важливих питань у різних сферах та галузях народного господарства.

Державно-приватне партнерство (ДПП) $€$ одним із основних механізмів демократичної ринкової економіки, який дозволяє в повній мірі реалізовувати потенціал розвитку відносин між державним сектором і приватним бізнесом. Крім цього, партнерство держави та бізнесу дозволяє збільшувати інвестиційний потік приватних компаній у процеси розширеного відтворення тих галузей, які знаходяться у безпосередньому підпорядкуванні держави та органів місцевого самоврядування, а також використовувати підприємницькі ініціативи щодо підвищення рівня бюджетної ефективності. У порівнянні 3 державними структурами, приватний бізнес та його менеджмент мають велику ресурсну мобільність і гнучкість, швидкість прийняття рішень, адаптованість до змін, здатність до інновацій та технологічних удосконалень 3 метою забезпечення конкурентоздатності. Органи державної влади, в свою чергу, можуть забезпечувати більш ефективну та успішну реалізацію проектів ДПП шляхом забезпечення стабільної правової бази, сприятливого політичного клімату в країні, а також застосування фрінансово-економічних інструментів 
впливу(підтримку та гарантії, субсидії та пільгове оподаткування). Таким чином, використання основних переваг бізнесу та державної влади слід використати у формуванні основ національної економіки та розвитку соціальної сфрери загалом і системи охорони здоров'я, зокрема.

Співробітництво держави та бізнесу у медичній галузі являє собою симбіоз можливостей і ресурсів учасників, враховуючи їх сильні сторони при виконанні поставлених завдань. Ключовою функцією органів державної влади при цьому виступає реалізація публічних соціальних зобов'язань, контроль за наданням безоплатних медичних послуг для населення, а також стратегічними пріоритетами і цілями країни, програмами соціального та економічного розвитку. Для приватного сектору при реалізації проектів ДПП у сфері охорони здоров'я важливим є своєчасно та в повному обсязі забезпечити надання послуг по найбільш оптимальній ціні, а також приймати участь у субсидованих державою програмах і проектах. Така рівновага державних, приватних та соціальних інтересів приводить, на нашу думку, до ряду соціально-економічних ефектів для учасників ДПП(див. рис.1).

Досвід розвинутих країн світу показує досить високу ефективність спільної діяльності держави та бізнесу в модернізації системи охорони здоров'я на основі форм та моделей державно-приватного партнерства. Так, у Німеччині, розповсюджений продаж державних лікувально-профрілактичних закладів інвесторам за символічну суму за умов забезпечення обумовленої суми інвестицій і виконання

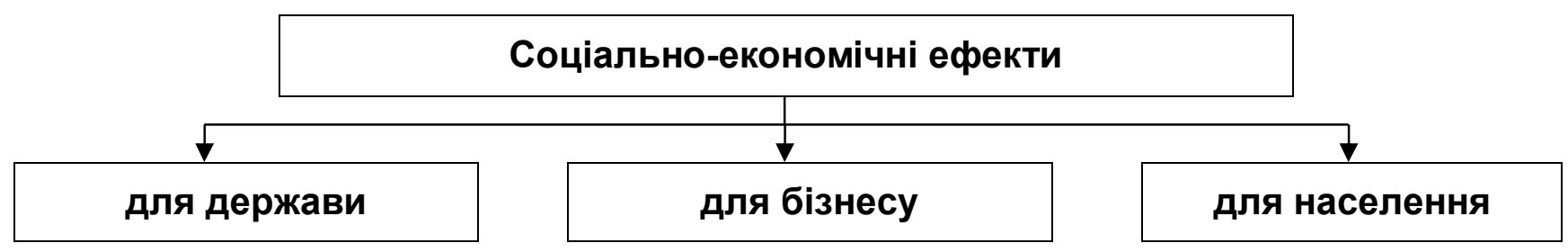




підвищення
ефрективності
управління і
обслуговування
державного майна;
залучення
інвестиційних ресурсів
у розвиток медичної
галузі;
розвиток регіональних
ринків капіталу,
технологій, товарів і
послуг;
розвиток ринку праці і
створення додаткових
робочих місць;
можливість оновлення
основних фондів.

стабільність і гарантія
отримання доходів;
користування
податковими пільгами
та префреренціями;
бюджетне
кредитування учасників;
наявність державних та
муніципальних гарантій;
бюджетне цільове
субсидування для
реалізації проектів дпп;
активізація залучення
іноземних інвестицій в
реальний сектор
економіки, досягнення
мультиплікаційного
ефекту.

рівень задоволення
населення
медичними
послугами;
загальний рівень
захворюваності та
смертності;
рівень забезпечення
населення закладами
охорони здоров'я та
медпрацівниками;
рівень кваліфікації та
досвідченості кадрів;
зростання рівня
життя населення
завдяки отриманню
медичних послуд
високої якості.

Рис. 1. Соціально-економічні ефекти для учасників державноприватного партнерства. *

*Джерело: складено автором на основі [1, с. 3131-3134; 2, с. 257]

зобов'язань по держзамовленнях. Завдяки цьому частка приватних лікувальних закладів у країні збільшилась майже у п'ять разів і становить близько 22\% [3, с.100]. При цьому використовуються три варіанти контрактів між партнерами: модель набувача, модель лізингу та модель здачі майна в оренду.

У Швеції практикується укладення договорів 3 приватними інвесторами на управління державними лікарнями, надання швидкої невідкладної допомоги, а також на надання послуг стосовно діагностики захворювань та лабораторних обстежень. 3 моменту впровадження практики ДПП вартість зазначених вище послуг для населення зменшилась майже на 40\% [4, с.13]. 
У Великобританії приватний партнер підтримує лікарняні заклади у робочому стані на протязі всього періоду їх експлуатації, але держава залишається відповідальною за якість наданих медичних послуг. Для об'єктивної оцінки ефрективності проектів ДПП у сфрері охорони здоров'я, у Великій Британії вперше було впроваджено модель «компаратора», основною метою якої $€$ забезпечення можливості об'єктивного порівняння проекту ДПП з аналогічним у державному секторі, який забезпечив би надання того самого комплексу послу. Компаратор дає можливість визначати показники для оцінки відповідності результатів до витрачених коштів [5].

Станом на 01.01.2017 року у Австралії процедуру приватизації уже пройшла майже третина лікувально-профрілактичних закладів. Основні договірні умови при реалізації проектів ДПП у цій країні включають контракт на управління строком не менше 15 років, зобов'язання обслуговувати усіх громадян за фріксованими розцінками та контроль за якістю надання медичних послуг. У результаті впровадження інституту державно-приватного партнерства витрати австралійського уряду на будівництво нових закладів охорони здоров'я скоротились на $20 \%$, а кількість населення, що обслуговують дані заклади зросло на 30\% [3, c.101].

Виходячи із напрацювань зарубіжного досвіду ДПП у сфрері охорони здоров'я, можна зробити висновок, що завдяки структурним змінам в економіці інститут державно-приватного партнерства здатний сприяти реалізації програм соціально-економічної модернізації 3 мінімальними витратами і ризиками для суспільного сектора. Досвід монополізації соціальної ссрери державою або бізнесом засвідчує в обох випадках низьку ефективність в економіках різних країн.

Копіювання та адаптація світового досвіду ДПП до вітчизняних умов $€$ досить складною, оскільки існує ряд розбіжностей як в 
нормативно-правових базах держав, так і в економічних важелях та стимулах, які застосовуються урядами країн. Але ефективність форм і моделей ДПП, що застосовуються у розвинутих країнах та досягнутий соціальний ефект у медичній галузі, являється вагомим стимулом для його вивчення при розробці власної моделі для української економіки.

Узагальнюючи досвід іноземних країн, можна стверджувати, що для ефрективної інтеграції інтересів держави і бізнесу у фрормі ДПП в Україні повинні бути сфрормовані необхідні умови, які умовно можна поділити на дві групи - зовнішні та внутрішні.

До зовнішніх умов слід віднести :

- створення рівних конкурентних можливостей - встановлення єдиних вимог до медичних установ не залежно від фрорми власності, реалізація права вибору пацієнтом страхової медичної організації;

- цінова політика - фінансування виключно за рахунок внесків у обов'язкове медичне страхування, врахування усіх статей видатків у величину тарифу та його економічне обґрунтування;

- перерозподіл ризиків - створення ризик-фондів для своєчасної стабілізації кризових ситуацій.

Щодо внутрішніх умов реалізації ДПП в системі охорони здоров'я, вважаємо, що до цієї групи доцільно віднести наступні:

- наявність висококваліфікованих кадрів, створення сприятливого мікроклімату у колективі - формування корпоративної культури, іміджу лікувальної установи, підвищення кваліфікації та навчання персоналу, матеріальне стимулювання працівників;

- наявність сучасного високотехнологічного обладнання та інформаційної інфраструктури;

- ефективний менеджмент в управлінні доходами та витратами, а також організація управлінського обліку у лікувальних закладах; 
- задоволення потреб пацієнтів завдяки підвищенню якості медичної допомоги та розширення спектру лікувальних послуг.

Дослідження властивостей державно-приватного партнерства загалом, та застосування його у системі охорони здоров'я зокрема, дає змогу зробити висновок про те, що йому притаманні як позитивні властивості, так і ризики успішного застосування в інтересах його учасників (табл. 2).

Таблиця 2.

\section{Переваги та недоліки державно-приватного партнерства}

у системі охорони здоров'я*

\begin{tabular}{|c|c|}
\hline & \\
\hline 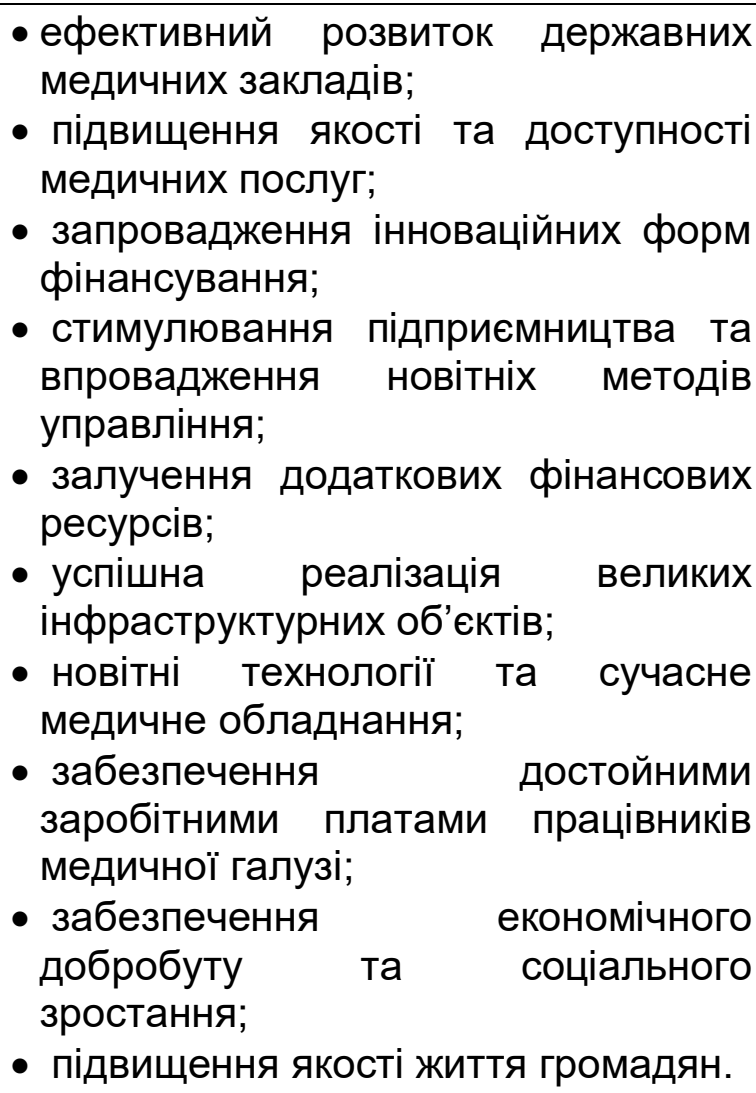 & 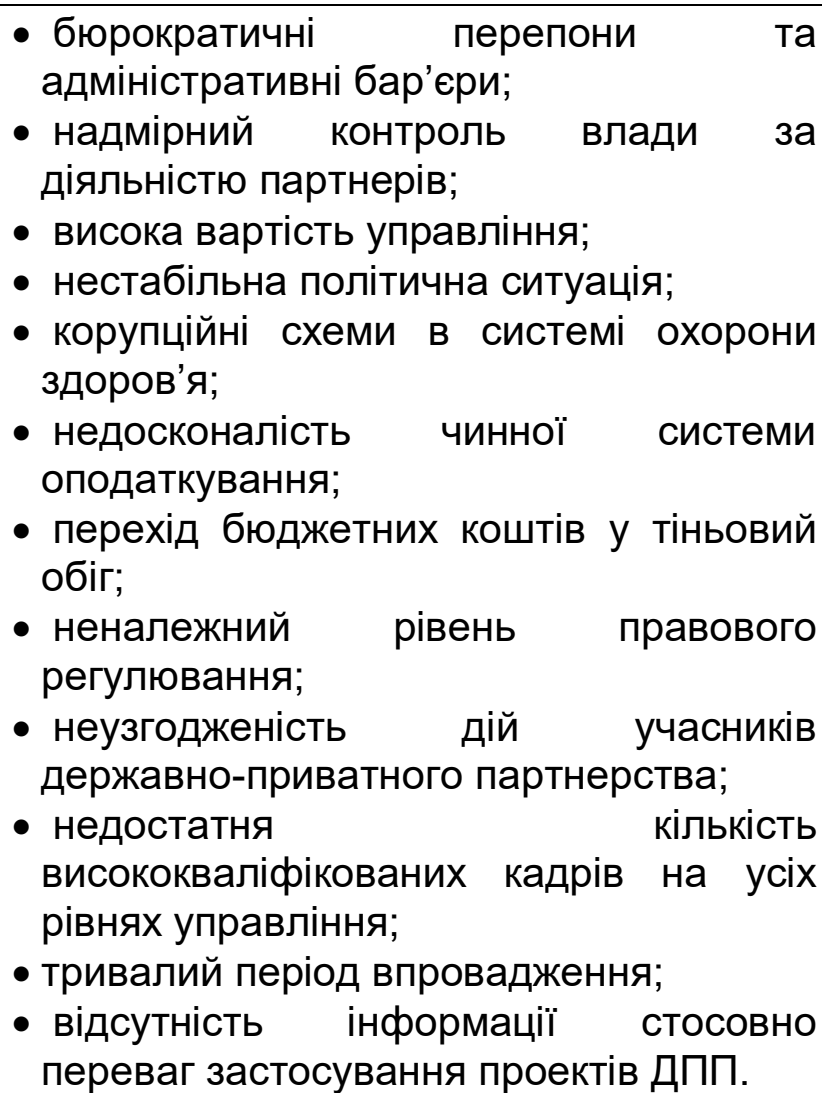 \\
\hline
\end{tabular}

*Джерело: складено автором на основі [6, с.145-146; 7; 8, с.41].

Враховуючи вищезазначене, уже сьогодні можна визначити основні напрямки використання ДПП у вітчизняній системі охорони здоров'я:

1) цільова підготовка кадрів та медична післядипломна освіта; 
2) організація стажування українських медиків у провідних клініках світу;

3) розвиток медичного приладобудування та фармацевтичної галузі;

4) впровадження високотехнологічної медичної допомоги;

5) розвиток добровільного медичного страхування.

Співпраця підприємницьких структур, органів державного управління та суспільного сектору при виконанні проектів ДПП забезпечить розвиток новітніх фрорм управління, зменшить навантаження на державний бюджет, стимулюватиме бізнес та допоможе вирішити ряд соціально-економічних проблем у нашій державі.

Висновки. Таким чином, перехід до використання системи державно-приватного партнерства дозволить суттєво покращити стан медичної галузі в Україні за рахунок додаткових джерел інвестицій, як фрінансових, так і інтелектуальних, а також оптимізувати видатки на охорону здоров'я. Окрім цього, ДПП сприятиме створенню умов для виходу даної галузі на біль високий технологічний рівень, забезпечить іiї стабільний розвиток та існування оптимального конкурентного середовища, розширить можливості вибору пацієнтом медичної установи та лікаря та підвищить якість медичного обслуговування. Різноманітні форми взаємодії при реалізації проектів державноприватного партнерства виступатимуть рушійною силою розвитку української системи охорони здоров'я та створять умови для оптимізації фрінансових ресурсів даної сфери та їх адресного використання. Розвиток інститут ДПП сприятиме розвитку ринку праці, фармацевтичної промисловості, виробництва медичного обладнання та техніки, а також підвищить інвестиційну привабливість медичної галузі, регіону та національної економіки загалом. 


\section{תimepamypa:}

1. Жердев P. A. Государственно-частное партнерство как драйвер развития отечественного здравоохранения / Р. А. Жердев // Российское предпринимательство.- 2015.- №16(18).- С. 3125-3138.

2. Shuliuk B. S. Financial instruments of public and private partnership development / B. S. Shuliuk // Scientific bulletin of Polissia. -2016. №3(7). - P.253-260.

3. Панова T. В. Опыт развитых европейских стран в использовании фрорм и моделей ГЧП в здравоохранении / Т. В. Панова // Вопросы экономики и права.- 2015.- №11. - С.99-102.

4. Варнавский В. Г. Государственно-частное партнерство в здравоохранении: международный опыт / В.Г. Варнавский // Управление здравоохранением. - 2010. - №1.- С. 9-16.

5. Павлюк К. Охорона здоров'я:спробувати механізми державноприватного партнерства [Електронний ресурс]. - Режим доступу: http://n-auditor.com.ua/uk/component/na_archive/141?view.

6. Добрусина М. Е., Завьялова Г. Н., Тулупова О. Н., Хлынин С. М. Государственно-частное партнерство как инновационная фрорма развития здравоохранения / М. Е. Добрусина, Г. Н. Завьялова, О. Н. Тулупова, С. М. Хлынин // Вестник ТГУ. Серия «Экономика». - 2011. №1(13). - C.142-148.

7. Павлюк К., Камінська О. Медична реформа: використаймо можливості державно-приватного партнерства [Електронний ресурс]. - Режим доступу: http://n-auditor.com.ua/ru/component/na_archive/1657.html.

8. Мартякова О. В., Трикоз І. В. Державно-приватне партнерство у сорері охорони здоров'я / О. В. Мартякова, І. В. Трикоз // Вісник 
Бердянського університету менеджменту і бізнесу. - 2011. - №1(13). - C.37-43.

\section{References:}

1. Zherdev R. A. Gosudarstvenno-chastnoe partnerstvo kak drayver razvitiya otechestvennogo zdravookhraneniya / $R$. A. Zherdev // Rossiyskoe predprinimatelstvo. - 2015.- №16(18). - S. 3125-3138.

2. Shuliuk B. S. Financial instruments of public and private partnership development / B. S. Shuliuk // Scientific bulletin of Polissia. -2016. №3(7). - P.253-260.

3. Panova T. V. Opyt razvitykh evropeyskikh stran $v$ ispolzovanii form $i$ modeley GChP v zdravookhranenii / T. V. Panova // Voprosy ekonomiki i prava.- 2015.- №11. - S.99-102.

4. Varnavskiy V. G. Gosudarstvenno-chastnoe partnerstvo $v$ zdravookhranenii: mezhdunarodnyy opyt / V. G. Varnavskiy // Upravlenie zdravookhraneniem. - 2010. - №1.- S. 9-16.

5. Pavljuk K. Okhorona zdorov'ja:sprobuvaty mekhanizmy derzhavnopryvatnogho partnerstva [Elektronnyj resurs]. - Rezhym dostupu: http://nauditor.com.ua/uk/component/na_archive/141?view.

6. Dobrusina M. Ye., Zavyalova G. N., Tulupova O. N., Khlynin S. M. Gosudarstvenno-chastnoe partnerstvo kak innovatsionnaya forma razvitiya zdravookhraneniya / M. Ye. Dobrusina, G. N. Zavyalova, O. N. Tulupova, S. M. Khlynin // Vestnik TGU. Seriya «Ekonomika». - 2011. - №1(13). S.142-148.

7. Pavljuk K., Kaminsjka O. Medychna reforma: vykorystajmo mozhlyvosti derzhavno-pryvatnogho partnerstva [Elektronnyj resurs]. Rezhym dostupu:

http://n-auditor.com.ua/ru/component/na_archive/1657.html. 
8. Martjakova O. V., Trykoz I. V. Derzhavno-pryvatne partnerstvo u sferi okhorony zdorov'ja / O. V. Martjakova, I. V. Trykoz // Visnyk Berdjansjkogho universytetu menedzhmentu i biznesu. - 2011. - №1(13). - S.37-43. 